\title{
Performance Evaluation of Single Ground Wheel Push Type Boom Duster for Row Crops
}

\author{
Hasan Nawaz Khan* and Ajay Kumar Sharma
}

Department of Farm Machinery and Power Engineering, Collage of Technology and Engineering Maharana Pratap University of Agricultural and Technology Udaipur, Rajastha-313001, India

*Corresponding author

\begin{abstract}
A B S T R A C T
Plant protection is an important part of crop cultivation, in which chemical method is most effective to control insecticide in comparison to other methods. Chemicals are usually

\section{Keywords}

Hand rotary duster, Dust through, Dust delivery, Air output, Dust application rate

\section{Article Info}

Accepted:

18 August 2020

Available Online:

10 September 2020 spread on plant through sprayer and duster. Duster is mostly used for dense foliage crops to kill insect using insecticides in form dust powder having particles size $(1-10 \mu \mathrm{m})$. Indian farmers mostly use belly mounted hand rotary duster for dusting. It is traditional method of dusting which have many limitations. Keeping all the limitation in mind to eliminate this by developing single ground wheel push type boom duster was developed, and it was evaluated in lab and its performance was check in field. The developed duster was first tested in lab of CTAE and found maximum dust through $1.91 \mathrm{~m}$ for given $0.0254 \mathrm{~m}$ diameter of dust conveying pipe which was fixed at dusting height of $0.55 \mathrm{~m}$ from the ground. The maximum dust delivery was found $151 \mathrm{~g} / \mathrm{min}$ using $0.0381 \mathrm{~m}$ diameter dust conveying pipe which was fixed at $0.55 \mathrm{~m}$ dusting height from ground. The air output was found $0.30 \mathrm{~m}^{3} / \mathrm{min}$ for given $0.0381 \mathrm{~m}$ dust conveying pipes at $0.55 \mathrm{~m}$ dusting height from the ground which was maximum value. Using best combination of selected above parameter according in lab test and using physical parameter of chickpea crops, the duster was tested in chickpeas field of plasticultural farm of CTAE and found theoretical field capacity, actual field capacity, field efficiency and dust application rate which was 0.1446 ha/h, $0.104 \mathrm{ha} / \mathrm{h}, 72$ per cent and $50.2 \mathrm{~kg} / \mathrm{ha}$ respectively.
\end{abstract}

\section{Introduction}

In India, about 60-70 per cent peoples are living in rural area and their main occupation are farming. Indian farmers are facing loss of crops due to biotic constraints like insect, pest attack on crops, destroyed approximate 40 per cent of crops while they are still in field (UN FAO).These biotic constrains are killing by chemicals method, because these methods is most effective, economic and reliable to control insect and pest in comparison to other method like mechanical, agronomical method. Chemical are spreading on plant in two form dust and liquid, in dust form mostly use for dense foliage crops and in dry land farming where water scarcity in summer season for agricultural purpose. Traditional farmer are 
using belly mounted hand rotary duster for dusting chemical in form of dust to plant, it has many limitation like laborious, time consuming, operator is exposing in chemical environment and ergonomically problem when dusting by using it for longer duration. There is need to mechanize it and to developed tractive operated or small engine operated duster, but engine operated duster consuming petroleum oils and create air pollution in environment. In India most of the farmers are small and marginal they are poor in economic basis and they are no capable to purchase big machine, big machine also not economically suitable for small fragmented land. These problem are overcome by developing a single ground wheel push type boom duster for row crop at farm power and machinery department of CTAE, MPUAT Udaipur Rajasthan, there is need to evaluate it in lab and felid for checking satisfactory operation.

\section{Materials and Methods}

\section{Performance Evaluation of the Developed Duster in lab}

Selection of parameter for testing of developed duster in lab whose detail are given in Table 1

The observation were taken by fixed the duster and direct current motor on a rectangular frame through nut and bolt and connected these two through chain and sprocket power transmission system, the rpm of dc motor were controlled through controller by changing the current supply to motor, put these frame on brick to simulate the height of dusting machine. The time was also measured through stop watch for dust delivery. The observations were taken for different combination of treatment and replication for selected dust. On the basis of observation the duster was evaluated for its performance in dusting of dust as shown in Fig. 1 using dust through, dust delivery, air output and leakage as performance parameters. The dependent and independent parameters which were tested are given in Table 1.

\section{Dust}

This is the medium through which we are applying pest in the form of dust in arid and semiarid zone of India by mixing pesticides in form of powered to dust uniformly and spared on dense foliage plant to kill the pest in place of water in spraying. Dust are most important constituent of pest applied in the form of dust on plant. There are different types and different mesh size of dust available in the market like soapstone dust, Calcite, Talc and china clay powder of 80 mesh to 700 mesh, in study selected soapstone and china clay powder of 100 mesh of dusts as shown in Fig. 2.

\section{Flexible hose pipe}

The function the of flexible hose pipe to conveying the dust from duster outlet to the particular row of crop with the support boom Here in this study selected three pipes of equal length but different inner diameter whose length and inner diameter as following $0.762 \mathrm{~m}, \quad 0.0254, \quad 0.0318, \quad 0.0381 \mathrm{~m}$ respectively as shown in Fig. 3.

\section{Variable speed D.C motor}

D.C motor function are to produced high initial torque and power to rune such machine which is required high staring torque, main thing of D.C motor and control assemble to easily adjusting the speed of motor according the requirement. The D.C permanent magnet can operate at multi speed and adopted at different power source, these motor require less current for lifting heavy load, by using 
this motor to operate the duster input shaft at $35 \pm 2 \mathrm{rpm}$ with the help of controlling as shown in Fig. 4.

\section{Digital weighing machine}

Digital weighing machine was used to measure weight of whole setup before operation and after operation of duster in lab test, a digital scale is comparatively more accurate as has high readability, range and comes with special features such as body mass index, memory feature and auto power as shown in Fig. 5.

\section{Hot wire anemometer}

Hot wire anemometer is a device used to measure velocity and direction of fluid. This can be done by measuring heat loss of wire, which is placed in fluid streams. The wire is hearted by electric current, probe of anemometer was placed in outlet of dust conveying pipes for measuring the air velocity coming out from the pipes and reading digitally was taken from display which was connected to probe as shown in Fig. 6.

\section{Test for air output}

The air output ware determined by hot wire anemometer method. The blower fan outlet of the duster was connected leaky proof with three different diameter pipes whose outer end were fixed at three different height from the ground, through three different diameter to the diameter of the blower fan outlet. Insert the probe of hot wire anemometer into the center of this pipe at a distance twice the inner diameter of pipe, from the end. Connect the probe handle to digitally display unit through connector as shown in (Fig. 7). Operated the fan at speeds like $35 \pm 2 \mathrm{rev} / \mathrm{min}$ of crank and noted the reading display on the screen
$\mathrm{Q}=\mathrm{A} \times \mathrm{V} \times 60$

Where,

$\mathrm{Q}=$ Air output of blower $\left(\mathrm{m}^{3} / \mathrm{min}\right)$

$\mathrm{A}=\frac{\mathrm{\pi}}{4} \times \mathrm{d}^{2}=$ Cross sectional area $\left(\mathrm{m}^{2}\right)$

$\mathrm{d}=$ inner diameter of dust conveying pipes

(m)

$\mathrm{V}=$ Air velocity whose value was taken from hotwire anemometer $(\mathrm{m} / \mathrm{s})$

The above test was repeated for at least three times and average of the values obtained was give the air output of the blower fan.

\section{Test for dust delivery}

The hopper was filled up to three -forth of its total capacity with different type of dust. The duster with all its working accessories shall be weighed to the nearest gram by using weighing machine. The duster was fixed temporarily on a frame and these frame put on brick to simulated to the height of dusting machine and it was operated continuously and uniformly at speed $35 \pm 2 \mathrm{rev} / \mathrm{min}$ of the duster in put shaft by variable torque motor and these two are connected through chain and sprocket, the rpm of duster in put shaft were easily obtained according to experiment by changing rpm of variable torque motor at the maximum discharge rate setting of the dust feed control mechanism for at least two minutes. (Anonymous, 1988) The mass of the duster with all accessories and setup was again determined by putting duster with setup as shown in right side of Fig. 8 on digital weighing machine as shown in left side of Fig. 8.

After that find difference between initial weight and final weight, this difference shows amount of dust delivered in grams, divided this difference by time of operation in minutes. The rate of discharge per minute determined. The above test were repeated for at least three times and calculate the average discharge rate per minute. 


\section{Test for dust through}

The hopper was filled up to three-forth of its total capacity with different powder like soapstone and china clay dust, set the duster, fixed the delivery pipe at different vertical position from the ground. The dust deflector was removed.

The duster was operated continuously and uniformly at speeds of $35 \pm 2 \mathrm{rev} / \mathrm{min}$ of the duster in put shaft by variable torque motor and these two are connected through chain and sprocket, the rpm of duster input shaft was easily obtained according to experiment by changing rpm of variable torque motor (Anonymous,1988). Measure the horizontal distances from the outermost point of the delivery pipe and the outermost point where dust falls on the ground as shown in Fig. 9. The above test were repeated for at least three times and calculate the average horizontal distance

\section{Test for leakage}

The hopper was filled up to three-fourth of its total capacity with different dust powder. Set the duster at its horizontal position and plug the blower fan outlet. The duster was operated at speeds of $35 \pm 2 \mathrm{rev} / \mathrm{min}$ for two minutes. (Anonymous, 1988). No leakage of dust was occur at any place in the duster during this test.

\section{Field test}

Based in lab result the developed machine was tested in CTAE farm field of chickpea was used for field performance evaluation. For the best combination value of conveying pipe diameter $(0.0381 \mathrm{~m})$, dusting height $(0.55$ $\mathrm{m})$ and dust (china clay dust) were taken. The outlet of dust conveying pipe was fixed at $0.55 \mathrm{~m}$ above from the ground and targeted toward the row as shown in Fig. 10.

\section{Field testing area}

Developed machine was tested for chickpea at plastic cultural farm College of Technology and Engineering, MPUAT Udaipur Rajasthan geographically, farm is located at $24^{0} 35 \mathrm{~N}$ latitude and $73^{\circ} 44 \mathrm{E}$ longitudes. Size of field $96 \times 30 \mathrm{~m}$, there were 48 beds, bed to bed spacing $1 \mathrm{~m}$ and bed length was $30 \mathrm{~m}$ long. Where chickpeas were shown on beds, two row per beds, row to row spacing was $30 \mathrm{~cm}$.

\section{Crop specification}

For field testing of developed duster selected crops was chickpeas, whose verity name is pertap-1, which was shown on beds, at the time of dusting maximum and minimum plant height of chickpeas was found to be $0.30 \mathrm{~m}$, $0.40 \mathrm{~m}$ respectively. Aim of dusting to kill pod borers of chickpeas

\section{Measure forward speed in field}

For calculating travelling speed, two poles 30 $\mathrm{m}$ apart are placed on the opposite side; also two poles were placed to form the corner of the rectangle, parallel to at least one larger side of the test plot. The speed was calculated from the time required to machine to travel the distance $30 \mathrm{~m}$. The average of such 5 reading was taken to calculate the travelling speed of machine in $\mathrm{km} / \mathrm{hr}$.

\section{Width of dusting}

Width of dusting operation was taken randomly in the field at different locations.

\section{Develop prototype was tested in chickpea for}

\section{Theoretical field capacity}

The theoretical field capacity of an implement is the rate of field coverage that would be 
obtained if the machine were performing its function $100 \%$ of the time at the rated forward speed and also covered $100 \%$ of its rated width (Kepner et al., 2005).

T. F. C $=\frac{W \times S}{10}$

Where T. F.C = Theoretical field capacity (ha/hr.),

$\mathrm{W}=$ Working width of implement (m),

$\mathrm{S}=$ Forward speed of dusting machine $(\mathrm{km} / \mathrm{h}$.), and

$10=$ Unit conversion factor.

\section{Results and Discussion}

\section{Laboratory evaluation of developed duster}

\section{Dust through}

Actual field capacity (Kepner et al., 2005)

A. F. C $=\frac{W \times S}{10} \times \mathrm{m}$

Where, A.F.C = Actual field capacity (ha/h)

$\mathrm{W}=$ Dusting width of implement (m)

$\mathrm{S}=$ Forward speed of dusting machine $(\mathrm{km} / \mathrm{h})$

$\eta=$ field efficiency

\section{Application rate}

Actual amount of dust delivered during dusting operation in field. Application rate was calculated by formula given below (Chandrashekar et al., 2018).

$\mathrm{A}=\frac{\mathrm{M} \times 10}{\mathrm{~W} \times \mathrm{S}}$

Where,

$\mathrm{A}=$ Application rate of dust $(\mathrm{kg} / \mathrm{ha})$

$\mathrm{M}=$ Dust delivery rate $(\mathrm{Kg} / \mathrm{h})$

$\mathrm{W}=$ Dusting width of duster $(\mathrm{m})$

$\mathrm{S}=$ Forward speed of duster $(\mathrm{km} / \mathrm{h})$

\section{Field efficiency}

Field efficiency is the ratio of actual field capacity to the theoretical field capacity; field efficiency is expressed in per cent (Sahay, 2008).

$\eta=\frac{A \cdot F \cdot C}{T \cdot F \cdot C} \times 100$

Effect of diameter of dust conveying pipes and height of dusting from the ground on dust through

\section{Dust delivery}

Effect of diameter of dust conveying pipes and height of dusting from the ground on dust delivery

\section{Air output}

\section{Field test of developed duster}

Selected china clay dust mixed with bromadiolone at 0.005 percent recommended pesticides for chickpea (Anonymous, 2014), $0.0381 \mathrm{~m}$ diameter of dust conveying pipe and $0.55 \mathrm{~m}$ dusting height from the ground on the basis of conducted label experiments and outlet end of dust conveying targeted toward the crop at $30^{\circ}$ clock wise from the horizontal boom. Operated the prototype of single ground wheel push type boom duster in chickpea of verity pertap- 1 in CTAE farm which was showing on bed, two rows per bed, row to row spacing $0.30 \mathrm{~m}$, bed to bed spacing $1 \mathrm{~m}$, chickpea height at the time of dusting $0.30 \mathrm{~m}-0.45 \mathrm{~m}$, dusting machine was operated between two bed and found forward speed of dusting, theoretical field capacity, actual field capacity, field efficiency and dust application rate were $1.92 \mathrm{~km} / \mathrm{h}, 0.1446 \mathrm{ha} / \mathrm{h}$, $0.104 \mathrm{ha} / \mathrm{h}, 72$ per cent and $50.2 \mathrm{~kg} / \mathrm{ha}$ respectively (Fig. 11-15). 
Table.1 Details of various parameters were taken for lab test of developed duster

\begin{tabular}{|c|c|c|c|}
\hline S. No & Variable & Parameter & Levels \\
\hline \multirow[t]{3}{*}{1} & $\begin{array}{l}\text { Independent } \\
\text { variable }\end{array}$ & $\begin{array}{l}\text { Dusting height from ground } \\
\text { (m) }\end{array}$ & $0.55,0.65,0.75$ \\
\hline & & $\begin{array}{l}\text { Diameter of dust conveying } \\
\text { pipe }(m)\end{array}$ & $0.0254,0.0318,0.0381$ \\
\hline & & Type of dust & Soapstone, china clay dust of (100 mesh) \\
\hline \multirow[t]{4}{*}{2} & $\begin{array}{l}\text { Dependent } \\
\text { variable }\end{array}$ & Air output $\left(\mathrm{m}^{3} / \mathrm{min}\right)$ & \\
\hline & & Dust delivery $(\mathrm{g} / \mathrm{min}$ ) & \\
\hline & & Dust through (m) & \\
\hline & & Leakage & \\
\hline \multicolumn{4}{|c|}{ Replication $=\mathbf{3}$} \\
\hline
\end{tabular}

Table.2 ANOVA showing effect of dust type, diameter of dust conveying pipe and dusting height from ground on dust through

\begin{tabular}{|c|c|c|c|c|c|}
\hline SOV & DF & SS & MSS & F CAL & $\begin{array}{l}\text { P- Value } \\
\text { Prob }>F\end{array}$ \\
\hline Dust type & 1 & 0.105 & 0.105 & $62.891^{*}$ & $<0.0001$ \\
\hline $\begin{array}{l}\text { Diameter of dust conveying } \\
\text { pipes }\end{array}$ & 2 & 3.474 & 1.737 & $1,042.275^{*}$ & $<0.0001$ \\
\hline Dusting height & 2 & 0.593 & 0.296 & $177.814^{*}$ & $<0.0001$ \\
\hline $\begin{array}{c}\text { Dust typex Diameter of dust } \\
\text { conveying }\end{array}$ & 2 & 0.180 & 0.090 & $54.005^{*}$ & $<0.0001$ \\
\hline Dust type $\times$ Dusting height & 2 & 0.002 & 0.001 & 0.569 & 0.57123 \\
\hline $\begin{array}{l}\text { Diameter of dust conveying } \\
\text { pipes } \times \text { Dusting height }\end{array}$ & 4 & 0.040 & 0.010 & $6.043^{*}$ & 0.00079 \\
\hline $\begin{array}{c}\text { Dust type } \times \text { Diameter of dust } \\
\text { conveying pipes } \times \text { Dusting } \\
\text { height }\end{array}$ & 4 & 0.002 & 0.000 & 0.258 & 0.90287 \\
\hline Error & 36 & 0.060 & 0.002 & & \\
\hline Total & 53 & 4.456 & & * Significant at $1 \mathrm{p}$ & \\
\hline
\end{tabular}

Table.3 ANOVA showing effect of dust type, diameter of dust conveying pipe and dusting height from ground on dust delivery

\begin{tabular}{|c|c|c|c|c|c|}
\hline SOV & DF & SS & MSS & F CAL & P- ValueProb $>$ F \\
\hline Dust type & 1 & 192.667 & 192.667 & $73.268 *$ & $<0.00001$ \\
\hline Diameter of dust conveying pipes & 2 & $1,024.704$ & 512.352 & $194.838^{*}$ & $<0.00001$ \\
\hline Dusting height & 2 & $10,318.259$ & $5,159.130$ & $1,961.923 *$ & $<0.00001$ \\
\hline Dust typex Diameter of dust conveying & 2 & 6.778 & 3.389 & 1.289 & 0.28803 \\
\hline Dust typex Dusting height from ground & 2 & 5.444 & 2.722 & 1.035 & 0.36548 \\
\hline $\begin{array}{l}\text { Diameter of dust conveying pipes } \times \text { Dusting } \\
\text { height from ground }\end{array}$ & 4 & 677.852 & 169.463 & $64.444 *$ & $<0.00001$ \\
\hline $\begin{array}{l}\text { Dust type } \times \text { Diameter of dust conveying } \\
\text { pipes } \times \text { Dusting height from ground }\end{array}$ & 4 & 5.111 & 1.278 & 0.486 & 0.74594 \\
\hline Error & 36 & & 2.630 & & \\
\hline Total & 53 & & & $*=$ Signifi & nt at 1 per cent \\
\hline
\end{tabular}


Table.4 ANOVA showing effect of diameter of dust conveying pipe and dusting height from ground on air output

\begin{tabular}{|l|c|c|c|c|c|}
\hline \multicolumn{1}{|c|}{ SOV } & DF & SS & MSS & F CAL & P- Value Prob $>$ F \\
\hline Diameter of dust conveying pipes & 2 & 0.072 & 0.036 & $1,128.085^{*}$ & $<0.00001$ \\
\hline Dusting height from ground & 2 & 0.022 & 0.011 & $348.598^{*}$ & $<0.00000$ \\
\hline $\begin{array}{l}\text { Diameter of dust conveying pipes } \times \\
\text { Dusting height from the ground }\end{array}$ & 4 & 0.006 & 0.001 & $43.102 *$ & $<0.00000$ \\
\hline Error & 18 & 0.001 & 0.000 & & \\
\hline Total & 26 & 0.101 & & $*$ * significance at 1 per cent \\
\hline
\end{tabular}

Fig.1 Setup for lab testing of duster

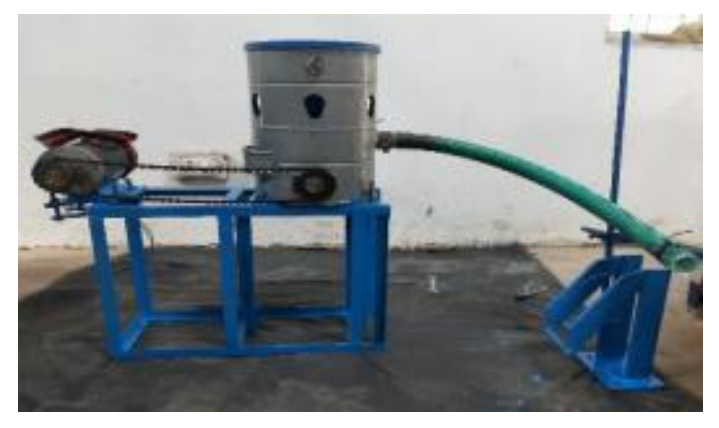

Fig.2 China clay dust and Soap stone dust

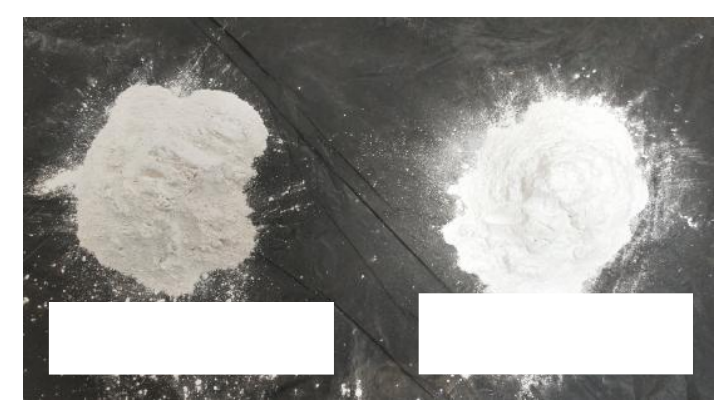

Fig.3 PVC flexible hose pipe of equal length and different diameter

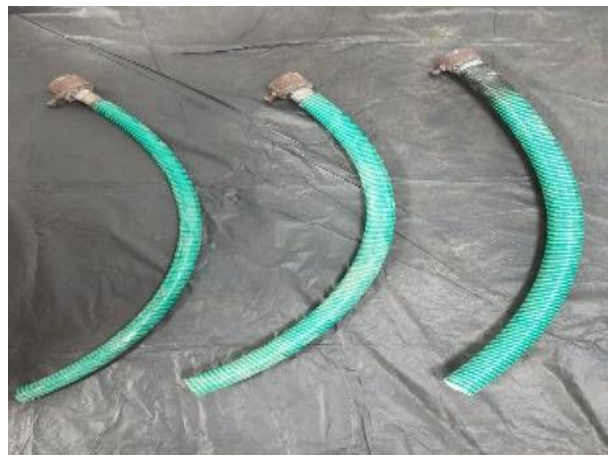


Fig.4 D.C motor

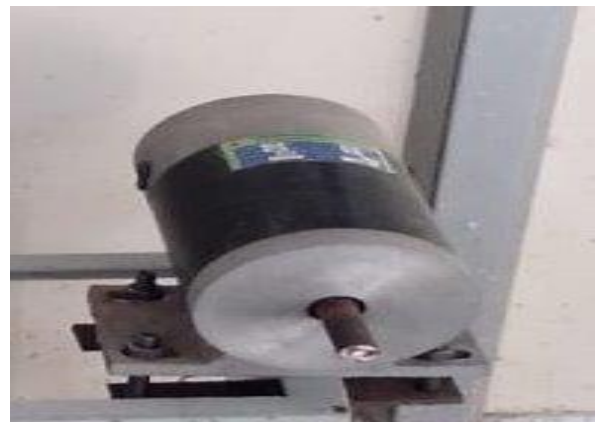

Fig.5 Digital weighing machine

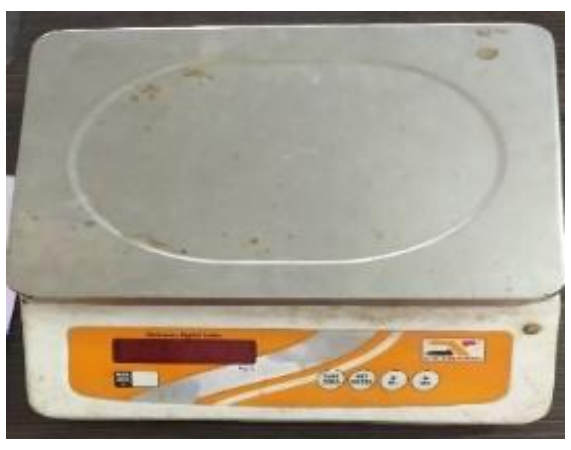

Fig.6 Hot wire anemometer

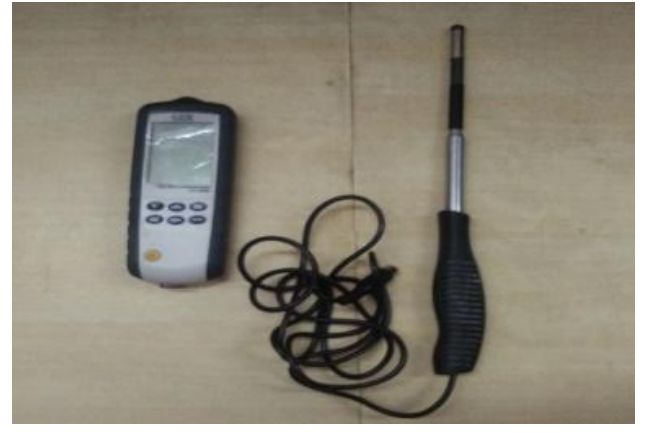

Fig.7 Determination of air output of the duster

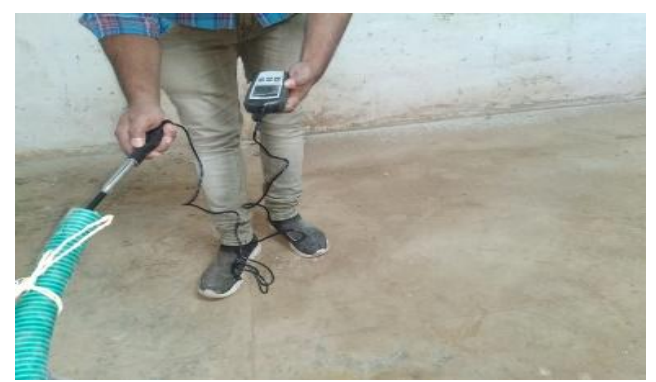


Fig.8 Setup for measuring the amount of dust delivered

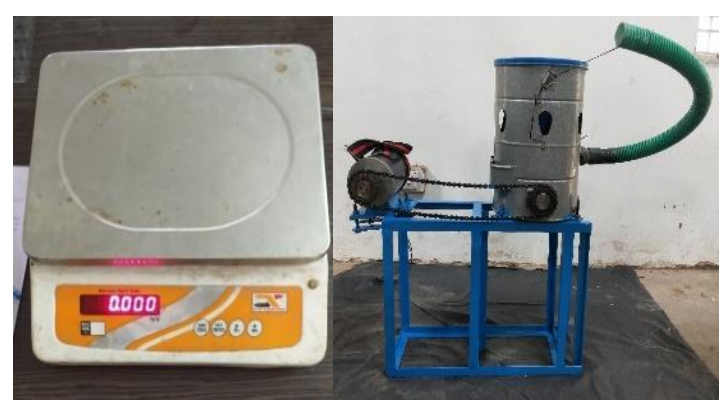

Fig.9 To measure the dust through in lab

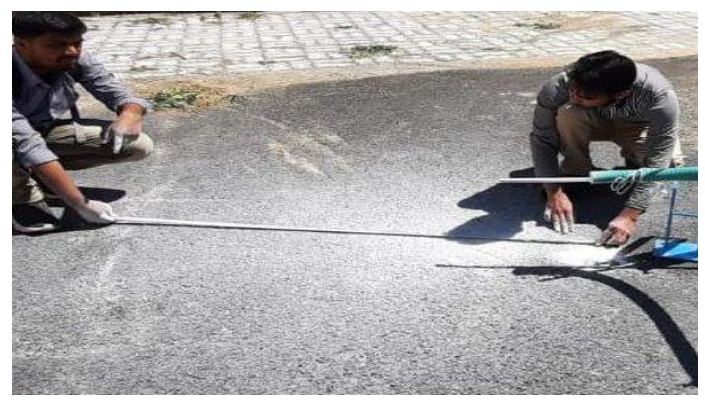

Fig.10 Field test of developed duster in chickpea field of CTAE farm
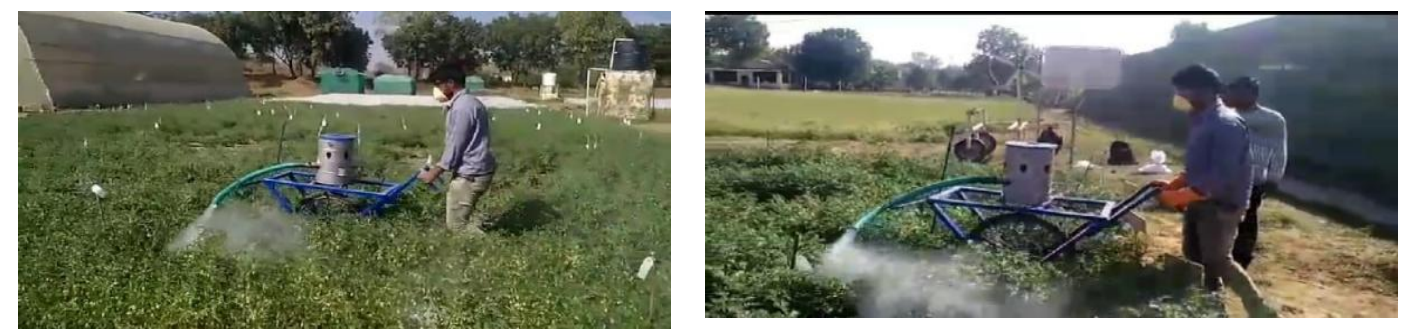

Fig.11 Effect of diameter of dust conveying pipe and dusting height on dust through for china clay dust

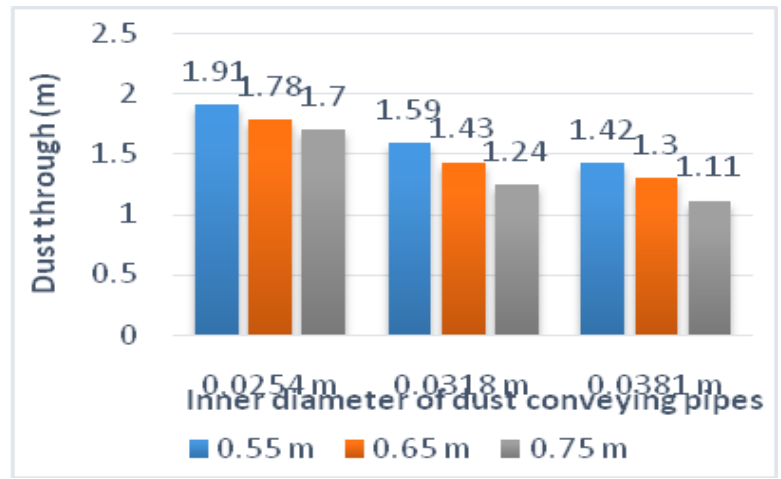


Fig.12 Effect of diameter of dust conveying pipe and dusting height on dust through for soapstone dust

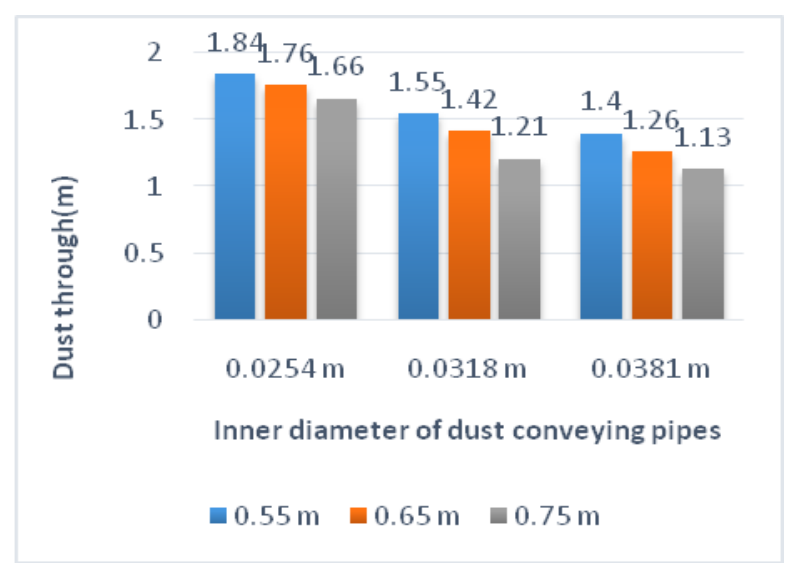

Fig.13 Effect of diameter of dust conveying pipe and dusting height on dust delivery for china clay dust

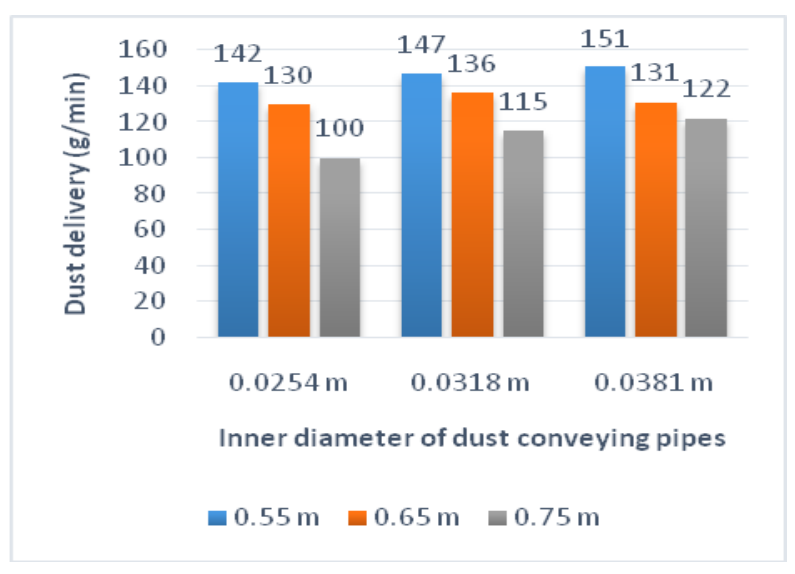

Fig.14 Effect of diameter of dust conveying pipe and dusting height on dust delivery rate for soapstone dust

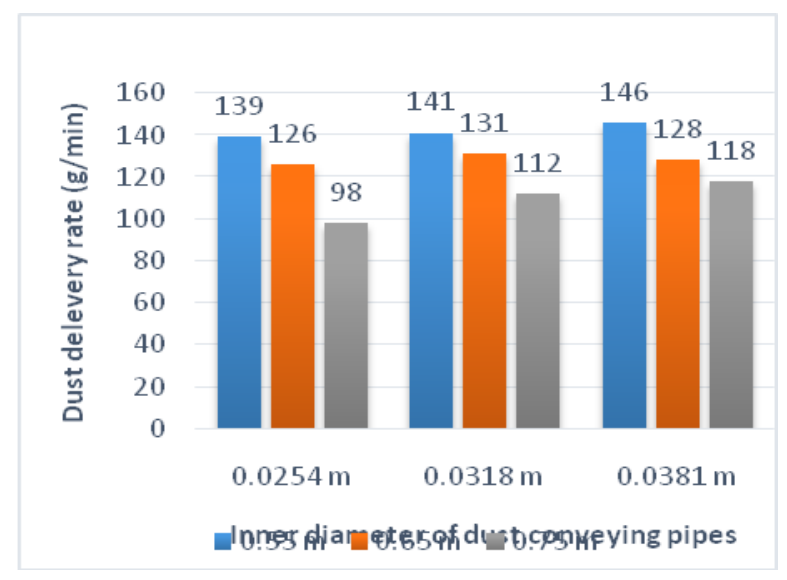


Fig.15 Effect of diameter of dust conveying pipe and dusting height on air output

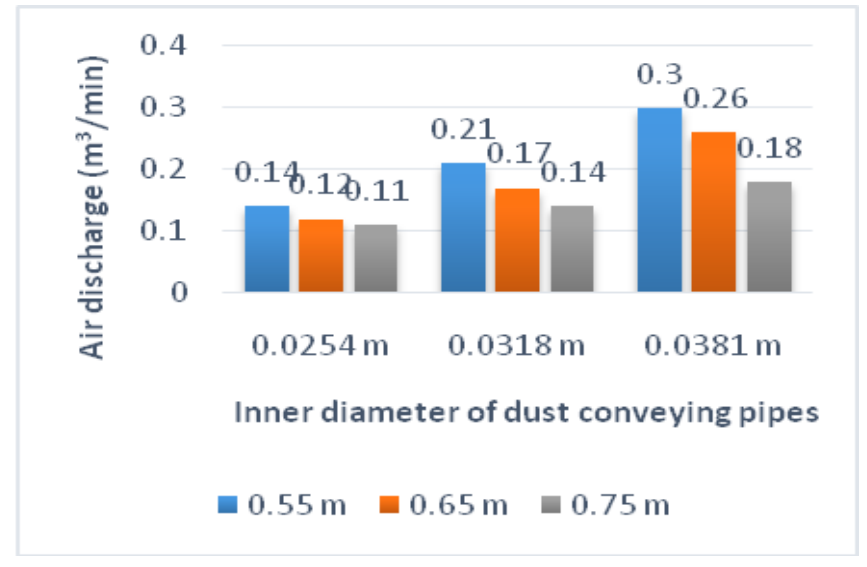

In conclusions

For china clay dust, the maximum dust delivery rate was found to be $151 \mathrm{~g} / \mathrm{min}$ with dust through of $1.42 \mathrm{~m}$ with $0.0381 \mathrm{~m}$ diameter of dust conveying pipe at $0.55 \mathrm{~m}$ dusting height from the ground.

In case of soapstone dust, the maximum dust delivery rate was found to be $146 \mathrm{~g} / \mathrm{min}$ with dust through of $1.4 \mathrm{~m}$ with 0.0381 $\mathrm{m}$ diameter of dust conveying pipe at $0.55 \mathrm{~m}$ dusting height from the ground.

The maximum air output was found to be 0.30 $\mathrm{m}^{3} / \mathrm{min}$ with $0.0381 \mathrm{~m}$ diameter of dust conveying pipe at $0.55 \mathrm{~m}$ dusting height from the ground.

Theoretical field capacity, actual field capacity, field efficiency and dust application rate were found to 0.1446 ha/h, 0.104 ha/h, 72 per cent and 50.2 $\mathrm{kg} / \mathrm{ha}$ respectively.

\section{References}

Anonymous. 1988. Methods of test for manually operated duster, IS12482:1988, Bureau of Indian Standard, New Delhi, pp.1-3.

Anonymous. 2014. Integrated pest management package for chickpea. National Center for Integrated Pest Management, LBS Building IARI Campus New Delhi pp.7-37.

Chandrashekar. Neeraja, J, and Raghavendra, V. 2018. Performance evaluation of solar operated push type Sprayer. International Journal of Current Microbiology and Applied Sciences 7: 1448-1456.

Kepner, R.A., Bainer, R. and Barger, E.L. 2005. Principles of farm machinery. CBS Publication \& Distribution PVT. LTD. pp. 25-26.

Sahay, J. 2008. Text book of elements of agricultural engineering. Standard Publishers Distributors Ansari road, Daryaganj, New Delhi pp. 233-235.

\section{How to cite this article:}

Hasan Nawaz Khan and Ajay Kumar Sharma. 2020. Performance Evaluation of Single Ground Wheel Push Type Boom Duster for Row Crops. Int.J.Curr.Microbiol.App.Sci. 9(09): 28372847. doi: https://doi.org/10.20546/ijcmas.2020.909.350 